To link to this article / Para enlazar con este artículo:

https://doi.org/10.14198/fem.2020.35.04

To cite this article / Para citar este artículo:

Wylie, Adele. "Climate conscious professional kitchens? Analysing the Scottish food sector through a feminist lens». En Feminismo/s, 35 (junio 2020): 95-125. Monographic dossier / Dossier monográfico: A critical practice of thinking otherwise: Bacchi, Gender and Public Policy Analysis, coord. Angela O'Hagan, DOI: $10.14198 / \mathrm{fem} .2020 .35 .04$

\title{
CLIMATE CONSCIOUS PROFESSIONAL KITCHENS? ANALYSING THE SCOTTISH FOOD SECTOR THROUGH A FEMINIST LENS
}

\author{
¿COCINAS PROFESIONALES CON CONCIENCIA \\ CLIMÁTICA? ANALIZANDO EL SECTOR ALIMENTARIO \\ ESCOCÉS A TRAVÉS DE UNA LENTE FEMINISTA
}

\author{
Adele WYLIE \\ Glasgow Caledonian University, Glasgow \\ adelewylie3@gmail.com \\ orcid.org/0000-0002-4200-526X
}

\begin{abstract}
As we enter what has been defined as a climate emergency, governments are formulating policy responses that address sustainability through low carbon transitions. This article examines the relationship between policy representation in climate mitigation, business and food policies, and the implementation of sustainable practices in professional kitchens. The restaurant industry is a major consumer of natural resources as many practices throughout the supply chain are carbon intensive. Following Carol Bacchi's "What is the problem represented to be?» framework, this article examines the extent to which policy representation of sustainability and food governance influences everyday practices in professional kitchens in Glasgow, Scotland, based on research undertaken in 2019. This study revealed that climate change, business and food policies promote the idea that sustainability will be achieved alongside economic growth, without considering the complexities of social inequalities. The policies significantly overlook the private sector responsibility to transform away from unsustainable practices, whilst the potential approaches to improve social and environmental sustainability are obscured. The article concludes by calling for policies
\end{abstract}

Los contenidos de la revista se publican bajo una licencia de Creative Commons Reconocimiento 4.0 Internacional (CC BY 4.0)

Feminismo/s 35, junio 2020, pp. 95-125 
to integrate issues of social justice in the representation of the problem to produce more transformative and socially equitable outcomes.

Keywords: Climate change; Sustainability; Professional kitchens; Policy; Gender.

\section{Resumen}

Este artículo examina la relación entre la representación de políticas públicas en mitigación climática, políticas comerciales y alimentarias, y la implementación de prácticas sostenibles en cocinas profesionales. La industria de hostelería es una gran consumidora de recursos naturales, ya que muchas prácticas en toda la cadena de suministro son intensivas en carbono. Siguiendo el marco analítico de Carol Bacchi «What is the problem represented to be?», este artículo examina hasta qué punto la representación política de la sostenibilidad y la gobernanza alimentaria influyen en las prácticas cotidianas en las cocinas profesionales de Escocia, a partir de un estudio realizado en 2019. Este trabajo revela que el cambio climático y las políticas comerciales y alimentarias promueven la idea de que la sostenibilidad se logrará junto con el crecimiento económico, sin considerar las complejidades de las desigualdades sociales. Las políticas pasan por alto significativamente la responsabilidad del sector privado de transformarse alejándose de prácticas insostenibles, mientras que los enfoques potenciales para mejorar la sostenibilidad social y ambiental quedan oscurecidos. El artículo concluye reclamando políticas para integrar las cuestiones de justicia social en la representación del problema para producir resultados más transformadores y socialmente equitativos.

Palabras clave: Cambio climático; sostenibilidad; cocinas profesionales; política; género.

\section{INTRODUCTION}

Climate change has been described as the «defining moral issue of the 21st century» (Levy and Patz 311) with consensus growing that we are living in a climate emergency (Cretney and Nissen 15; Lenton et al. 592; Ripple et al. 8-12). This emergency has been described as a manifestation of unsustainable human activities (Hulme 899). These unsustainable practices, sparked by energy intensive technological advances since the industrial revolution, have resulted in global biodiversity loss and degradation, vulnerable global economies, increasing inequalities, and public disconnect from political agendas (Giddens 1-16). In response, many countries around the world are attempting

Feminismo/s 35, junio 2020, pp. 95-125 
to mitigate these effects through the implementation of policies at both international and country level. However, scholars from different disciplinary backgrounds problematize emerging policy approaches because they may reproduce or exacerbate inequalities that mostly affect the poorest and most marginalised people in society. Underlying these critiques is the concern that policymaking in general tends to be gender, race and class blind, neglecting how such intersecting factors enable or constrain the agency of individuals to respond (Eveline and Bacchi 87).

The first substantive international policy response to climate change was the United Nations Framework Convention on Climate Change (UNFCCC). The framework highlighted the need for the concentration of greenhouse gases in the earths' atmosphere to be significantly reduced to prevent triggering an irreversible anthropogenic climate catastrophe. The UNFCCC called for an international response to address greenhouse gas emissions through international treaties to produce protocols or agreements (UNFCCC). The most recent treaty flowing from the framework is the Paris Climate Agreement (2016), in which world leaders committed to reduce greenhouse gas emissions with the hope of preventing the global average temperature from rising more than two degrees. Emission reduction targets have been set, at country level, for both 2030 and 2050 (Du Pont et al. 5). Scotland is taking an ambitious approach towards reaching its 2050 climate targets, aiming to be a carbon neutral country by 2045 . The Scottish Government are progressive in their climate ambitions and Scotland's first minister Nicola Sturgeon maintains that the environmental and social gains called for within environmental, climate and business policies will be met without compromising the country's economic growth. Despite this positive intent, the Scottish Government's policies are still framed within an economic growth discourse. Without addressing the social oppression and environmental degradation, two significant consequences of capitalism (Rose and Cachelin 518-525), Scotland could be overlooking potential social and environmental trade-offs that may occur alongside a low carbon transition. If economic gains are prioritised, this could result in an unjust transition.

In considering the restaurant industry, it is clear that this industrial sector has consistently benefited from access to natural resources and food produce from all over the world. This commodification of nature has contributed 
towards negative environmental, social, cultural and political consequences for many people around the world (Moore 97). Restaurants should therefore be considered as potential major actors in assisting countries move towards a sustainable transition. Such engagement would entail embracing social, environmental and economic obligations in a whole systems approach, rather than the prioritizing of one. Arguably, if all dimensions of sustainability are in equilibrium, socio-economic inequalities and environmental degradation should progressively reduce. The question arises then in relation to policy objectives such as those expressed by the Scottish Government and, more widely, as to whether such necessary principles are reflected within government policies. Is there a visible and meaningful policy focus on combining concern to eliminate the harmful commodification of natural resources and workers, central to climate change mitigation policy? Or is there a fine selection on the policy menu but the real cooking is on the back burner?

This article examines the extent to which the Scottish Government's climate change, business, and food policies are influencing the environmental conscience and everyday practices of head chefs in Glasgow. Examining current practices in professional kitchens helps to gauge if and how governmental policies are supporting the drive for more sustainable business practices. This article progresses from a succinct literature review that explores the relationship between gender, nature, sustainability and business. It is informed by feminist and ecofeminist scholarship that calls for a transformation of traditional organizational structures, built upon masculine ethics. As patriarchal societies are associated with dominance over women and exploitation of nature, the evaluation of gendered norms and roles within society and within sustainable transitions are now as relevant as ever. It is therefore essential to examine the relation between sustainability, gender, and business. As Allwood (10) suggests, focusing on gender in the context of climate change and sustainability highlights the lived experiences of women, and the ways in which gendered dynamics play out in practice and how these might be changed, and change them. Secondly, this article critically evaluates the way in which climate, business and food policies in Scotland frame and represent the issue of sustainability as a direct response to climate change. To do so, this article will draw from Bacchi's framework «What is the problem represented to be?» (Bacchi, Policy problems 5). It investigates whether such representation of

Feminismo/s 35, junio 2020, pp. 95-125 
sustainability conceals underlying institutional discrimination, in turn minimizing the potential for authentic sustainable practices to be implemented. The policy analysis is combined with qualitative empirical data gathered from semi-structured interviews with head chefs, in order to determine to what extent the 'problems' represented in these policies are consistent with experiences in professional kitchens. This article concludes by calling for governmental climate, business and food policies to integrate issues of social justice more transparently and substantively in the framing and definition of the problem of sustainability.

\section{LITERATURE REVIEW}

\subsection{Policy Representation}

Over the last twenty years, feminist theorist Carol Lee Bacchi has made a significant contribution to policy analysis, disputing the idea that public policies are developed as means to solve arising, identifiable societal challenges (Practice; Policy problems; WTP). In 1999 Women, policy and politics: The construction of policy problems (1999) Bacchi argued that societal issues can be shaped, moulded or created through the way in which governments frame and represent the issue they are responding to, extending this approach into an analytical tool to examine the ways in which policy problems are constructed. By asking «what is the problem represented to be?» (WPR), this analytical framework explores the ways in which assumptions and presuppositions result in misrepresentation of a problem, leaving underlying issues at the root of the problem masked, silenced or ignored. Although Bacchi acknowledges that problem representation can be instrumentalised at times for political gains, she calls for the WPR approach to be used at a level which will «probe the deep conceptual underpinnings of problem representations» (Bacchi, WTP 1). According to Carol Bacchi and Susan Goodwin (7) this method of analysing policy can be transferred to many policy areas. As such, the framework is applied here to dissect Scottish Government's climate and food policies as discourse, whilst semi-structured interviews complement this analysis by gauging how policy is being interpreted and translated (or not) into practice. 


\subsection{Connecting gender and the commodification of nature}

Feminist and ecofeminist perspectives have importantly reconceptualised the relationship between nature and society, and within society in relation to gender. Ecofeminism suggests that before technological and economic progress became the main indicator of a successful society, societies were more egalitarian and the relationship between nature and society was more equitable and sustainable. Ecofeminist scholars invoke a rebalancing of power between nature and society and a return to pre-scientific and pre-industrialisation (Leach 67-85), when nature's value was more than just instrumental (Kneel). Concurrently, domination over nature is to be examined in relation to domination within society. Ecofeminist theorists such as Ruether and Merchant argue that we live in a patriarchal, capitalist society produced by historical domination and oppression of both women and nature. Such hierarchal power over nature has created a nature-human «dualism», which both the feminist scholar Plumwood (43-60) and environmental ethics scholar Attfield argue is the root cause of our contemporary climate and ecological crises. Altogether these arguments are key in rethinking the core values of sustainability in relation to gender.

Ecofeminism, with its association to feminist activism (Leach 67-85), has been perceived at times as too radical and critiqued by scholars such as Brohman and Leach (67-85) for its one-dimensional analysis of the relationship between women and nature. Brohman argues that ecofeminism fails to acknowledge intersecting factors such as race, class and privilege, which shape every woman's identity differently. Intersectionality has become a theoretical-methodological model in its own right and an increasingly important analytical tool within climate research to understand behaviours and vulnerabilities (Aavik 509-527). Therefore, there is a need to evaluate gendered differences which enable or constrain one's ability to adapt and change behaviour. That is not to say that one gender is more instinctively concerned with nature preservation than the other. Yet, to create change, we need to dig beneath the surface and reveal the motivations and gendered power structures at institutional, societal, organisational level, which dictate how much control people have over their own options. The next section examines how 
gendered barriers within organisations constrain or enable transformation of organisational and economical structures.

\subsection{Sustainability in a masculine business world}

Through her studies of gendered organisations, Acker highlights that traditional hierarchy within an organisation always favours men, as the roles of power and authority are given to those who can commit to full-time paid work («Hierarchies»139-158). Unlike women, men have been able to have a full-time job and life long career as their wives or mothers would generally care for their children on their behalf. On the other hand, choices for women in relation to paid employment have been more limited. Due to the gendered structural constraints, women must divide their commitments between family-work time, as societal norms and gendered expectations dictated that raising children was the role of the mother, and work was the role of the father (Gerson 8-24). Consequently, women have been more likely to be positioned in lower-ranking roles within organisations. Over thirty years ago, Morrison et al. (1987) described the phenomenon of few women securing roles within the most powerful positions as the «glass ceiling», a metaphor of the invisible barrier preventing women from progressing upwards, still in daily use. Acker suggests that the glass ceiling may never be broken through by women, unless there is an overall transformation within the organisational and economical structures which foster inequalities in the first place («Glass ceiling» 199-21).

Steinberg describes male dominated work environments as organisations built upon «masculine values», suggesting that since men were historically in positions of power, they have had the greatest influence over the way in which a business -its structure, ethos, and identity- was organised (576581). In such businesses women are under-represented and subject to the dominant masculine bias and hierarchy, detrimental to their status in terms of position and power. Steinberg further argues that men, who have an interest in maintaining their superior status, do so by reproducing gendered stereotypes such as dominant behaviour in the work place (Steinberg 576-581). This «masculine ethic» produces a male dominated work environment (Moss 245-266), and is adopted by the organisational leader, whether they are a man or woman (Steinberg 576-581). 
These gendered dynamics are the norm in professional kitchens which are known for their male dominated workforce, especially in decision making roles, and associated with anti-social working hours and high pressured work environments. Deborah Harris and Patti Giuffre (27-52) highlight that men still outnumber women in leadership roles within professional kitchens. These environments are known for being adrenaline fuelled, aggressive, sexualized misogynistic (Cooper 681-704). Stereotypes of cooking as a «feminine» activity and a «male ethic» combine in efforts of male head chefs to disassociate their job role from feminine stereotypes. Male chefs may «compensate» by overt displays of stereotypical masculine traits in their kitchen such as stamina, resilience, no emotion under pressure, and the ability to work for long hours in extreme conditions (Koch 75-79; Nilsson 647-663). All levels of staff in professional kitchens are known to endure long working hours and unregulated working conditions. Women mostly must «prove» themselves to be as capable as male chefs to withstand the masculine working environment of a professional kitchen (Harris and Giuffre 27-52). Therefore, as signalled by Acker, if the gendered stereotypes, ideologies and fundamental structure of a work place continue to favour male employees, then that organization will continue to be male dominated («Hierarchies» 139-158).

The leadership style of kitchens has also been associated with bullying, demeaning verbal abuse and a hierarchical structure that resembles that of the military (Koch 75-79; Nilsson 647-663). Testing these propositions, a study of women in the Swedish Armed Forces (Kronsell, «Methods» 108128; «Practices» 280-298) explored the experiences of women and gendered relations within a traditionally hegemonic masculine environment. The author found that women are made to feel an excluded minority within this masculine institution and underscores the importance of documenting the largely overlooked gendered experiences of women in the forces. Listening to the experiences of some of the women provides the insight needed to help understand and transform masculine institutions, especially ones which are not exposed to outside influences such as activism and social movements.

Altogether these studies invite us to reconsider sustainability in the context of a masculine business world and raise important questions as to how the structures of a work place enable or constrain change. In line with these considerations, this study problematizes sustainability in the context of the

Feminismo/s 35, junio 2020, pp. 95-125 
gendered professional kitchen and the article explores the discursive ambitions of climate and food policy and the reality of food catering as a business activity.

\section{METHODOLOGY}

The design of this research was influenced by personal experience as a professional chef of 18 years and my perspective as a feminist researcher. As a female professional within a male dominated industry, I was exposed to the challenges of working in a masculine environment. Further, working in kitchens raised my awareness towards sustainability concerns such as resource consumption and the carbon footprint of restaurants. These experiences have kindled my research focus on sustainability in the food industry.

The analysis of sustainability as a policy discourse and of the practices in restaurants was carried out in three stages. Firstly, this article identified the relevant policy documents from the Scottish Government which were developed as a climate mitigation strategy and in the attempt to ensure food sustainability in the country. Annex 1 contains the analysis of these documents using Carol Bacchi's feminist framework «What is the problem represented to be?» (Policy problems), applying each of the following questions to the policy documents:

- What is the problem represented to be within the policy? Are there references to restaurants, gender, gender equality, social inequalities, environmental protection, responsibilities for the private sector in climate mitigation?

- What assumptions underlie this representation?

- In what ways does this representation mask, obscure or silence underlying issues, such as institutional discrimination and absence of accountability to act?

- What are the potential effects of this representation?

- How can this representation be reconceptualised or replaced?

Thirdly, this analysis was combined with data collected from ten semi-structured face to face interviews, carried out with six male and four female head chefs in Glasgow. Glasgow is Scotland's largest city with a reputation for leisure and nightlife with a strong hospitality sector base and a progressive 
outlook. These factors influenced the selection of Glasgow as a mini-case study to explore the issues in focus. During the interviews participants where asked open ended questions. This allowed participants to freely express their opinions and perspectives. Interviews were carried out at the restaurant in which the head chefs were employed and lasted between 20 and 90 minutes, depending on participants' knowledge and interest in the topic of the interview. I explained to all participants that I am also a chef. This, I believe, resulted in an open and authentic discussion as participants knew they were engaging with a person that understood the context.

During the interviews, all chefs were asked questions on sustainability, including internal and external drivers influencing their everyday practices in kitchens, training of junior staff, personal values regarding sustainability and gendered dynamics in kitchens. Interviews were recorded and transcribed in full and data was analysed for evidence of the effects (or lack of) on everyday practices of head chefs. All of the participants were anonymized and given a pseudonym: M-number for male chefs and F-number for female chefs.

Through the coding process, the following key themes were identified: perceived frictions between environmental and social responsibilities in the restaurant industry; limited «kitchen conscience», with sustainability ranking low in perceived responsibility of chefs; normalisation of gendered discrimination and «glass ceiling» in kitchens; social injustice in kitchens. I then examined if and how these concerns were represented in Scottish climate and food policies.

\section{THE POLICY REPRESENTATION OF CLIMATE CHANGE MITIGATION AND FOOD SUSTAINABILITY}

Drawing on Bacchi's framework «What is the problem represented to be?» (Policy problems), this section analyses the way in which the Scottish Government is framing Scotland's response to the global climate emergency and to what extent this discourse values social and environmental inclusiveness. 


\subsection{Climate policies}

Scotland's climate policies centre around the problem of climate change as a global threat, which the government is tasked to address in order to reach the emission targets set out in the 2016 Paris Agreement. The government plans, policies and acts for climate mitigation focus and Scotland's commitments to the Paris Climate Agreement, emphasise economic growth alongside the necessary low carbon transitions. Analysis of the Scottish Government climate policies revealed that restaurants remain outside the governing sphere of nation-wide climate mitigation policies (Scottish Government, Good food; Climate Change (Scotland) Act, 2009). Although the climate policies stress the need for Scotland to meet the emissions reduction targets by 2050, no explicit accountability is placed on the private sector. Food systems are only discussed in the context of sustainable agriculture (i.e. food production). No focus is placed upon food consumption and production practices further down the food system, including the restaurant industry. In the eyes of the government there seems to be no significant correlation between restaurants as food consumers and greenhouse gas emissions. Consequently, these policies are potentially encouraging a «business as usual» rather than a transformative approach, within smaller industries such as hospitality.

Documentary analysis reveals that the term sustainability is often used, without being unpacked and critically defined. As a result, they reflect a very superficial interpretation of this concept whereby the possible trade-offs between current economic growth and socio-environmental pillars of sustainability are not addressed and, even less so, resolved. The impacts of reducing carbon emissions on different societal groups are not outlined. On the contrary, individual behaviour is discussed and addressed assuming homogeneity, without considering how dimensions such as gender, economic status and race intersect in enabling or constraining agency of individuals (as well as organisations) attempting to reduce emissions.

Waste management, rather than food consumption, is the sector that is addressed in more detail. Scotland has ambitious waste reduction targets set for 2025, reflected within Scottish Government climate policies. Waste management and recycling are seen as priority from business to household level. The Scottish Environmental Agency (SEPA) and the Climate Change 
Act (2009) both focus on waste prevention, recycling, and reduction of packaging as a means to ensure sustainability. This is a key part of climate policy measures, and both public and private sectors are legally obliged to recycle their plastic, metal, glass and paper, with lack of compliance leading to a monetary fine.

Overall, these policies are cherry picking ways in which changes can be instrumental in assisting the government to reach their 2025 and 2050 targets. At the same time, these policies encourage economic growth and overlook the fact that social and environmental dimensions may be compromised by maintaining a core focus on growth rather than sustainability. By sending the message that economic growth will prosper with a low carbon transition, and that a low carbon future is an essential investment that can bring future financial opportunities to Scotland, climate change mitigation is portrayed as a business opportunity rather than an international response to a climate emergency. This «profit from Paris» narrative is not the basis of a just transition.

\subsection{Government Food Related Policies}

The main message of food related policies is that the Scottish food system is unsustainable because the country is not self-sufficient. Restaurants and food businesses are only discussed in relation to food and health policies (Scottish Government, Good Food Consultation; Good Food Measures; Recipe for Success). In June 2016, Fergus Ewing MSP and Cabinet Secretary for the Environment announced a new food policy aimed at ensuring that «people from every walk of life take pride, pleasure and benefit from the food that they buy, serve and eat day by day» (Scottish Food Commission 1). Following this announcement, a consultation process was initiated by the government. In this context, the Scottish Food Commission recommended that:

All food businesses, including restaurants, cafes and other outlets, should be licensed in the same way as applies to alcohol and betting. A condition of the license [...] should be that, food preparation, purchasing and serving staff are trained in the impacts of food and health and sustainability matters commensurate with their work activity (1). 
The government, however, does not want to extend the policy to «private food related businesses» as this would significantly increase their costs and «unfairly disadvantage them compared to competitors» (Scottish Government, Climate Change Plan 1). By adopting such measures in the public sector the government is acknowledging the need for change and for tightening regulation. At the same time, by not extending this regulation to the private sector, it has openly prioritised economic gains over sustainability concerns within this sector. Ironically, in the same year (2018) the Scottish Government published the Food Tourism Action Plan, aimed at stimulating $£ 10$ billion growth in the food industry over 10 years. This initiative is promoted as a way to «capitalise on the best of our natural resources» (Scottish Government, Good Food Measures 15). This is arguably a missed opportunity for food policy to include measures which influence or promote sustainability in restaurants as integral to stimulating business, opting instead for an economic growth agenda, blind to sustainability practices, to dominate. In the process, the trade-offs between economic growth and sustainable food businesses are overlooked. As for the climate policies above, the notion of sustainability used does not challenge sectors to make difficult choices and does not provide clear guidance on how to achieve sustainability. Furthermore, these policies do not address feminist concerns and values such as inclusiveness, and agency to make decisions and are silent on the relationship between gender and socio-economic inequalities despite activity elsewhere by the Scottish Government to promote its «Fair Work» agenda, as discussed below.

\subsection{The Government Business Pledges}

Gender discrimination in the work place still exists and could impact the productivity of businesses: this is the message sent by the Scottish Government in partnership with businesses through the Scottish Business Pledge (2015), and the Fair Work Convention (2015). Occupational segregation in the labour market has been acknowledged by the Scottish Government as a policy priority, as evidenced in various policy statements by the Scottish Government and its continued funding of gender equality organisations such as Equate Scotland and Close the Gap. These initiatives seek to resolve gendered occupational segregation (horizontal and vertical) within paid employment where

Feminismo/s 35, junio 2020, pp. 95-125 
women are less present in higher paid senior positions. Furthermore, they analyse data on gender equality in the workplace and the right to equal pay and campaign for change. Emily Thomson and Naveed Hakeem (6-7) highlighted that occupational segregation and the gender pay gap in Scotland's labour markets may be intensified through vulnerable economic activities, as a result of the 2007 global financial recession. The restructuring of the labour market after the subsequent recession led the Scottish Government to attempt to more closely reflect the relationship between economic growth and inequalities, with the message to businesses that gender equality and maximizing the potential of women in the all areas of the labour market, can enhance productivity.

The Scottish Government's gender pay-gap action plan «A fairer Scotland for women» (2019) introduced by the First minister of Scotland Nicola Sturgeon, proclaimed her commitment to reducing the gender pay gap in the next four years, and sent a message to women in Scotland that «no glass ceiling should prevent you from reaching your dreams» (1). In the «Scottish Business Pledge, 2015» the Scottish Government calls for businesses to be more racially and gender balanced as a way to make businesses more «productive». The pledge highlights that many women are working below their skill set and that employing more women and utilizing their capabilities can only be a positive contribution to businesses (Weaver et al. 6).

Framing gender equality as a support to increased productivity represents the problem of gender equality as a business growth problem to be addressed and aims to reveal underlying discriminations that Scottish businesses have not yet challenged head on. However, without addressing the root causes and everyday practices of such discriminations, this framing can silence the ways in which the fundamental structure of businesses, specifically professional kitchens and the restaurant sector, can prevent women, particularly those with families from progressing upwards. If many women are working below their skill-set, then the organisational structure in which they are being squeezed into must be flawed, yet women continue to be presented as having untapped economic value, rather than people who have the same right to employment and professional progression as men. Of course this representation of women is a way of speaking the language which appeals to businesses and potential employers. By portraying women as having economic value,

Feminismo/s 35, junio 2020, pp. 95-125 
the business pledge aims to assist women in securing employment. However, this «promotion of a business case for equality» (Thompson 128) is risky as it leaves gender equality in the hands of the private sector that can decide to adhere to this idea on a voluntary basis and only if this is beneficial to them. A further risk is that businesses will make room for women in a structure that remains flawed, rather than transforming their business structure to eliminate institutional discrimination. Flexibility as a key aspect of transformation within a business structure has been proposed by Emily Thomson and Naveed Hakeem (17-18), based on the premise that gender balance within the work place can enhance business performance. The implementation of more flexible working conditions which are shown to increase the well-being of employees, have the potential to attract many women who would otherwise face under-employment or are struggling to balance work-family responsibilities (Thomson and Hakeem 2).

\section{POLICY 'PROBLEMS' IN PRACTICE: SUTAINABILITY AND GENDER IN PROFESSIONAL KITCHEN}

In this section I examine the extent to which the policy «problems», as represented in the policy analysis above, are understood and addressed in practice by head chefs in professional kitchens. Determining the «conscience» of a kitchen is instrumental to understand whether chefs are aware of the social, environmental and economic consequences of their actions.

The analysis in this section is based on current practices in professional kitchens. The case study findings reveal that many underlying issues constrain the necessary inclusion of sustainable values and practises within professional kitchens. Furthermore, as chefs operate in a highly masculine environment, the gendered culture of kitchens was evident. Gendered assumptions regarding the need to choose between a career or a family were common. Such gendered experiences and perceptions are in line with Acker's («Hierarchies») and Steinberg's analysis of the way in which organisational structures favour men and with recent accounts of hierarchies in professional kitchens (Harris and Giuffre 27-52). 


\subsection{Organisational norms and behaviours}

Professional kitchens are a prime example of a working environment that is structured in a way in which women (and men) face constraints in securing more senior positions whilst raising a family. The Scottish Government calls for businesses to be more racially and gender balanced as a way to make businesses more productive. The problem is framed simply as needing to address women being in positions that are way below their skillset. This representation fails to capture the discrimination female chefs in this study have experienced in the workplace on a daily basis because of the way businesses are structured. To illustrate, there are only a few female head chefs in Glasgow. While male chefs explain this as women's inflexibility to fit in the industry, they do not consider the possibility that the industry should be changing to accommodate women. For M2, women cannot have both a senior role and a family, asserting that «it just doesn't work for them». Mothers looking for a family/work life balance could only progress to a senior position if they «commit further [than 45 hours a week]». In Ml's kitchen, the only female chef is a mother who needs to complete her 36 hours each week over three days, in order to balance family life. To M1 this lack of flexibility is a «hindrance»:

If there is someone who not necessarily does not want to pull their weight, but can't pull their weight because they have a child and can't do extra work, it means the people around them have to pick up the slack, which is not really fair in this industry. In other industries it would be fair, but not in hospitality.

Female chefs who cannot take on extra working hours when needed, he continues, create an unfair work balance for other staff members that do. Yet, neither M1 nor M2 question the fact that working mothers are asked to choose between family life and a successful career in the industry, but fathers are not. These male chefs seem to also imply that whilst men are in the position to progress and have a family, women (likely to have bigger responsibilities in the household) need to choose. As M2 puts it, «women that don't have kids and want to focus on their career, can go to the top!». As a result, women maintain a low-status and a lower paid role if they want to have a family and stay in the industry. 
Family life is only one reason as to why there are few female head chefs. Many women (F4, F1 and F2) emphasized that they had to work twice as hard as men to have the same position or gain a promotion. F4 felt awkward saying this as she thought the idea could sound a «bit out there». Yet, 3 out of 4 female participants felt the same way. Gender seems to be a topic that is never discussed within the industry, especially by female chefs, perhaps this is because it could be portrayed as a weakness.

Another challenge women face is being taken seriously by junior staff. F2 mentioned that she is always aware of her gender in the kitchen. In her first experience as sous chef (second in command), she found that her assertiveness was a problem for the men in the kitchen. On multiple occasions she was called a «bitch» and she felt she was taken less seriously than her male counterparts. Both F4 and F2 feel the industry is «hard for a woman» and that they «need to have a thick skin» if they want to progress. F4 mentioned that to be taken seriously and deter unwanted sexist and patronising comments from colleagues and the restaurant suppliers, she must communicate sternly to the point of coming across as «almost rude». Some female chefs believe they are also not taken seriously by suppliers and delivery drivers. F1 and F4 recall suppliers entering the kitchen and failing to acknowledge them as the head chef, insisting on talking to the male junior chefs instead. Both had to persuade the supplier that they were in fact the head chef. On many occasions, F4 was made uncomfortable by a delivery driver asking her to «smile» and «cheer up». She further elaborated: «my job is stressful, I am not there to smile and welcome people. These comments would never be said to the (male) owner». Gendered relations in the kitchen, therefore, could limit professional progression and the interactions with male colleagues could become female chefs' «glass ceiling».

Male chefs do not seem to consider gender as an important aspect of their job: «I never really think about gender» (M6). When men consider gender, they interpret it as a synonym for women, as if men do not have a gender. M4's response to a question on gender dynamics in kitchens, for instance, focuses on women: «I think the girls knew what the environment was like before they started». M1 aptly summarises these dynamics by explaining that racism, misogyny and sexism are present throughout the industry «as it exists 
throughout all of society». He believes such negative traits are exacerbated within kitchens as the anti-social working hours and harsh working environments can lead many chefs to live «isolated lives». He adds that «kitchens are not exactly hives of progressive thought, they are places of people with very isolated lives and ideas».

Furthermore, evidence from interviews underscores the need for policy -at governmental and organisational levels - to acknowledge and address some of the underlying dynamics of established behaviours that both produce further incidences of gendered behaviours and barriers to their resolution. Working practices that undermine collective and individual wellbeing contribute to poor working conditions and the ability of managers to engage in and promote change (Murray-Gibbons and Chris Gibbons 32-40). Such issues can affect a chef's ability and mind-set, preventing them from prioritising sustainability in their work routine. For example, F1, M2, F2, and F4 emphasised that the physical and mental stress can take its toll on chefs. A 33-year-old head chef (M2), mentioned that he is tired every day of his life: his average workday starts at 9 a.m. and ends at lam. During this time, he is constantly on the move and under pressure. F1 emphasised the mental stress she has experienced as a head chef, to the point that she recognised that it was «changing her personality» in a negative way. She also witnessed «talented» and «creative» chefs «self-medicate» with drugs and alcohol to calm down from the «natural adrenaline» and «stress» experienced on a daily basis at work.

Another factor that may affect the wellbeing of the chefs is their income and working hours. Only a few chefs (M2, F2 and F3) confirmed their staff were being paid more than minimum wage, whilst in all other cases staff were on minimum wage. The average working week is 45 hours before overtime. F4 said she can work up to 60 hours per week and her job leaves her no opportunity for a family-work life balance. These working conditions are unsustainable and financially unrewarding for chefs. This reality is overlooked in policies, which fail to unpack the complexities of an unsustainable food system in relation to an unequal society. For the chefs to be a part of the change towards sustainable restaurants, their well-being must be as valued as the profit they generate. 


\subsection{The effects of policy representation in practice}

The Scottish Government's minimising of the leadership role and responsibilities of the private sector in climate change mitigation is also clearly reflected in the perceptions and actions of head chefs. For example, the interview data shows that head chefs fail to see a direct link between their actions and climate change, and in turn, they feel no responsibility to be actively sustainable on a professional level. When asked what sustainability meant to them, most chefs used buzzwords such as «recycling», «zero waste» and «local produce». Given the extent to which chefs are interconnected with and reliant on the natural environment, it was surprising that, for example M3 found «nothing came to mind» when he thought about sustainability. As the head chef of one of the most prestigious restaurants in the city, M3 is in the luxurious position of charging his customers a far higher price than the average restaurant. With these higher costs to the customer, M3 prioritizes quality of products over animal welfare, environmental degradation and the local economy. For example, he pointed out that «local» is a grey area for him and classified England and continental Europe as buying locally. He wants the best quality product and it does not matter where he gets it from «if I can get a better chicken from France than up the road, then I am getting it from France». Evidently, sustainability does not formulate his standard of a «good quality» product. The way M3 classifies «local» reflects a key oversight of the Scottish Government policies, which promote a local sustainable food system without providing guidance on what sustainable and local are. Under these circumstances, «local» will continue to be a «grey area» and chefs' attempts to be sustainable may be counterproductive.

All participants, however, agree that the most important part of their job is to make a profit. Therefore, a chef with the best social and environmental intentions will always be limited by the budget. Even F1, by far the most environmentally aware chef, mentioned that her kitchen is as sustainable «as the budget can afford». M6, M5 and M2 emphasised many times that their hands were tied as they cannot pass certain costs on to the customers.

A second effect is that restaurants are not yet exploring their potential contribution towards a sustainable transition and it does not appear that they 
will anytime soon. Knowledge and awareness are key factors in driving change (Meinzen-Dick et al. 29-25), yet all the chefs interviewed mentioned that they do not engage in discussions about environmental issues with junior staff members. Even when head chefs make more sustainable choices, these are not discussed with junior staff. For example, when M6 replaced cod with hake on his menu, he did so because he had read it was unsustainable, however, he never discussed the reason with the junior staff. He admitted he could do a lot better in communicating and teaching, but the structure and nature of the business means that there is always something more «pressing» and that «you are just trying to make it through each day without a disaster happening». With junior staff not being trained to be environmentally and socially conscious of their actions, it raises the question, where are the junior chefs learning about their environmental responsibilities and the consequences of their everyday practices if not in the work place?

Consequently, the next generation of kitchen leaders are not being equipped with ecological literacy and awareness. With little guidance from government, chefs are vulnerable to being misinformed regarding climate issues. Policy representation plays a role in informing the private sector in what problem exists and how they should respond. If this representation obscures reality, the response will be ineffective.

Solid waste management represents an exception. Government regulation on recycling and waste management have had an impact on chefs. All chefs confirmed they recycle and comply with regulations, even though they perceive them as a burden. All participants mentioned the recycling protocols in place as the only influence at government and council level, they are aware of, in terms of enforcing the implementation of sustainable practices. This shows that regulation can influence the industry and promote positive behaviour changes. Recycling is, however, a tiny contribution towards a global problem and has the potential to create the illusion that we can generate as much waste as we desire because we have recycling facilities in place. 


\section{DISCUSSION AND CONCLUSIONS}

In this article, I have analysed the gap between discursive ambitions of Scottish food and climate policies and the reality of the restaurant industry. The combination of professional practice, personal experience and policy analysis make an original contribution to the literature, with the additional perspective of a feminist analysis. This article has revealed through a feminist lens that policies put in place to steer Scotland on a path of sustainability and a low carbon transition have promoted the idea that these goals will be achieved alongside economic growth. This representation silences the multiple ways in which social and environmental dimensions may be compromised in the process. Similarly, government policies do not directly call upon the private sector to contribute significantly towards a sustainable low carbon transition. Climate policies do not focus on food consumption, thus also silencing the correlation between restaurants and greenhouse gas emissions. Furthermore, food policies that are mostly concerned with promoting the Scottish food industry, often overlook sustainability practices in restaurants and the wider hospitality industry. Overall, the way in which the Scottish Government is framing Scotland's response to the global climate emergency and food governance does not mainstream how gender, economic status and race intersect in enabling or constraining agency of individuals and businesses attempting to reduce emissions. By silencing gendered discriminations, potential approaches to improve social and environmental sustainability are also obscured.

The case of head chefs in professional kitchens illustrates how policies promote economic growth over social and environmental sustainability. Professional kitchens are still male dominated and characterized by an adrenaline fuelled, aggressive and sexualized environment, as identified by MurrayGibbons and Chris Gibbons (32-40). The gendered dynamics in professional kitchens resemble in many ways those described by Kronsell («Methods» 108-128) in her study on the Swedish Armed Forces. In both sectors women face a predominantly masculine environment, in which they feel they are treated differently. A further contribution of the research in this article is that it reveals that women chefs must work harder to gain their position or to be respected by their male colleagues. Furthermore, in both cases gender is not 
perceived as an issue by men, whose masculinity is implicitly seen as «the norm». Women, on the contrary, live the consequences and struggles of their associated femininity and the gendered structures of their professional and private lives. From an ecofeminist perspective, which places gender in relation to environmental sustainability, the fact that kitchens are dominated by patriarchal norms and capitalistic logics has important implications. The silencing of gendered discriminations and lack of convincing attempts towards transforming unsustainable nature-society relations mirror the commodification of nature described by Ruether in 1975 and Merchant in 1980. It also raises a question for future research as to how much progress there has been over forty years on from their observations.

The Scottish Government Business Pledge is an important significant attempt to address the issues women face in professional environments. However, it fails to identify and address the structural barriers within businesses that cause women to work below their skill-set. As argued by Kendrigan, "while treating women the same as men would provide a significant improvement in the lives of many women, treating men and women the same will not solve the problems of institutional discrimination» (221). In practice, this means that ensuring that female chefs have the same employment opportunity as male chefs might entail treating them differently (McPhail 39-61; Kendrigan 221) to avoid institutional discrimination from impacting their right to work. Different needs may require different treatment in order to give someone an equal opportunity, which is far more complicated than treating everyone the same (Bagilhole 144-147). It is the need for transformations within unequal systems that policies should be addressing, rather than a passive approach which leaves room for business as usual. This resonates with Acker's argument that breaking the glass ceiling will require a profound transformation of organisational and economical structures that foster inequalities in the first place ( Glass ceiling» 199-217).

In conclusion, in order to produce more transformative and socially equitable outcomes, as Bacchi has consistently argued (Practice; Policy problems; WTP) policy analysis requires to be informed by evidence and understanding of the gendered differences that shape experiences of public policy decisions. That means when examining what a problem is represented to be, the analysis 
needs to consider gendered social, economic, and political dimensions, rather than assume a gender neutral reality. Furthermore, integrating an intersectional perspective into policy making processes will contribute to achieve this goal. An intersectional lens, in the context of sustainability and gender, can highlight the limitations and advantages individuals and groups have towards being sustainable, in direct relation to the socio-economic, power and gendered structures within which they are situated.

In the future, a sustainable restaurant industry would be one which refrains from solely prioritising economic gains over their corporate responsibility to ensure environmental stewardship and gender equality. If sustainability entails contributing towards environmental targets within a just society, it cannot be manipulated into an economic strategy that perpetuates current growth patterns. In considering the restaurant industry, this means that a real sustainability agenda would need to place value on the wellbeing of chefs as well as to address the business pressures, for chefs to buy fully into sustainability as a set of working and productive practices.

To conclude, this article has spotlighted several issues of relevance for future research to explore further. This includes examinations of engagement with sustainability through continuous professional learning and knowledge sharing, trade-offs between economic drivers, environmental values and social inequalities in professional kitchens, and barriers and opportunities to establish socially and environmentally just professional kitchen. 


\section{ANNEX 1. POLICY ANALYSIS}

\begin{tabular}{|c|c|}
\hline Climate Policies & Analysis \\
\hline \multirow{5}{*}{$\begin{array}{l}\text { 1. Scottish Government } \\
\text { Climate Change Plan. The } \\
\text { Third Report on Proposals } \\
\text { and Policies 2018-2032. } \\
\text { 2. Climate change } \\
\text { (Scotland) Act, } 2009 . \\
\text { 3. SEPA, Waste (Scotland) } \\
\text { Regulations } 2012- \\
\text { Guidance for Restaurants E } \\
\text { Bars, 2012. }\end{array}$} & $\begin{array}{l}\text { What the problem is represented to be: } \\
\text { - Climate change is a global threat and Scotland must play its } \\
\text { part in reaching the emission reduction } 2050 \text { targets set out in } \\
\text { the Paris Agreement. }\end{array}$ \\
\hline & $\begin{array}{l}\text { Assumptions: } \\
\text { - A low carbon future is an essential investment which can } \\
\text { bring future financial and social opportunities to Scotland. } \\
\text { - Economic growth must coexist and prosper with low carbon } \\
\text { transitions. } \\
\text { - No trade-offs required between the different dimensions of } \\
\text { sustainability (social, environmental and economic). }\end{array}$ \\
\hline & $\begin{array}{l}\text { Effects: } \\
\text { - Economic gains, encourages business as usual attitude. } \\
\text { - Society and economy are seen as a homogenous whole. } \\
\text { Behaviour is discussed and addressed assuming homogeneity, } \\
\text { with no reference to how gender, economic status, race } \\
\text { intersect in enabling or constraining agency of individuals and } \\
\text { organisations attempting to reduce emissions. } \\
\text { - Emphasis on waste management and recycling. } \\
\text { - Can deflect sustainability responsibilities as businesses are not } \\
\text { held accountable for actions. }\end{array}$ \\
\hline & $\begin{array}{l}\text { Silences: } \\
\text { - Gender blind/race/class blind. } \\
\text { - Trade-offs of low-carbon transitions and vulnerability of } \\
\text { marginalised groups. } \\
\text { - Inequalities. } \\
\text { - Failure to acknowledge the explicit roles and responsibilities } \\
\text { of individuals and the private sector. } \\
\text { - Accountability for emissions and what behaviours need to } \\
\text { change. }\end{array}$ \\
\hline & $\begin{array}{l}\text { Disrupted/contested/contradictions/reconceptualization } \\
\text { - The international response to a climate emergency as } \\
\text { something to profit from. Without profit would there be no } \\
\text { action? } \\
\text { - Who is really benefitting from this 'just' transition? } \\
\text { - Concretely, what does the behaviour change entail and for } \\
\text { whom? } \\
\text { - Why is the private sector remaining neutral in this? To remain } \\
\text { a stabile contributor to the economy? } \\
\text { - «Profit from Paris» }\end{array}$ \\
\hline
\end{tabular}

Feminismo/s 35, junio 2020, pp. 95-125 
Climate conscious professional kitchens? Analysing the Scottish food sector through a feminist lens

\begin{tabular}{|c|c|}
\hline Food Policies & Analysis \\
\hline $\begin{array}{l}\text { 1. Scottish Government. } \\
\text { Recipe for Success: } \\
\text { Scotland's National Food E }\end{array}$ & $\begin{array}{l}\text { What the problem is represented to be: } \\
\text { - The Scottish food system is unsustainable and the country is } \\
\text { not self-sufficient. }\end{array}$ \\
\hline $\begin{array}{l}\text { Good Food Nation. } \\
\text { 2. Scottish Food } \\
\text { Commission. } \\
\text { Recommendations from the } \\
\text { Scottish Food Commission } \\
\text { for the implementation of, }\end{array}$ & $\begin{array}{l}\text { Assumptions: } \\
\text { - We should adopt a more local approach to fix this. } \\
\text { - Inequalities would not exist within a more localised food } \\
\text { system. } \\
\text { - Micro food producers could cope with the increasing demand } \\
\text { in a sustainable way. } \\
\text { - Access to food, affordability and eating habits will change } \\
\text { through the adoption of a «buy local approach». }\end{array}$ \\
\hline $\begin{array}{l}\text { Good Food Nation Bill. } \\
\text { 3. Scottish Government. } \\
\text { Good Food Nation } \\
\text { proposals for legislation: } \\
\text { analysis of consultation }\end{array}$ & $\begin{array}{l}\text { Effects: } \\
\text { - Does not unpack the complexities of an unsustainable food } \\
\text { system and unequal society. } \\
\text { - The responsibility of change is put on the public sector which } \\
\text { deflects it away from individuals and the private sector. Non- } \\
\text { sustainable method. }\end{array}$ \\
\hline $\begin{array}{l}\text { 4. Scottish Government. } \\
\text { Good Food Nation } \\
\text { Programme of Measures, } \\
\text { September 2018: }\end{array}$ & $\begin{array}{l}\text { Silences: } \\
\text { - Gender blind regarding social and institutional gender } \\
\text { discrimination. } \\
\text { - Uncritical approach to sustainability with no mention of } \\
\text { potential trade-offs between dimensions of sustainability. }\end{array}$ \\
\hline $\begin{array}{l}\text { 5. Scottish Tourism } \\
\text { Alliance. Food Tourism } \\
\text { Action Plan, } 2019 . \\
\text { 6: Scottish Government. } \\
\text { Recipe for Success } \\
\text {-Scotland's National Food } \\
\text { and Drink Policy. }\end{array}$ & $\begin{array}{l}\text { Disrupted/contested/contradictions/reconceptualization } \\
\text { - Buying local could be more expensive than purchasing lower } \\
\text { quality produce in the supermarkets. } \\
\text { - A transition to local buyers/growers considers environmental } \\
\text { benefits but what about increased emissions through } \\
\text { transportation and agriculture? } \\
\text { - Who determines what is local and what is good? } \\
\text { - Promotes the living wage as a method to aid access to good } \\
\text { food. }\end{array}$ \\
\hline
\end{tabular}

Feminismo/s 35, junio 2020, pp. 95-125 
Climate conscious professional kitchens? Analysing the Scottish food sector through a feminist lens

\begin{tabular}{|c|c|}
\hline Business report/pledge & Analysis \\
\hline \multirow{5}{*}{$\begin{array}{l}\text { 1. Scottish Business } \\
\text { Pledge, 2019. The Scottish } \\
\text { Government in partnership } \\
\text { with businesses. } \\
\text { 2. Tackling Occupational } \\
\text { Segregation in Scotland: A } \\
\text { report of activities from the } \\
\text { Scottish Government Cross- } \\
\text { Directorate Occupational } \\
\text { Segregation Working Group }\end{array}$} & $\begin{array}{l}\text { What the problem is represented to be: } \\
\text { - Institutional discrimination in the work place still exist today } \\
\text { and it could be impacting the productivity of businesses. }\end{array}$ \\
\hline & $\begin{array}{l}\text { Assumptions: } \\
\text { - Businesses which are equal, fair and socially sustainable can be } \\
\text { far more productive. } \\
\text { - «Woman are working below their skill level». Therefore, } \\
\text { businesses are encouraged to employ more women and utilise } \\
\text { their capabilities. } \\
\text { - That productivity of a business is more important than } \\
\text { eradicating underlying discrimination. }\end{array}$ \\
\hline & $\begin{array}{l}\text { Effects: } \\
\text { - Promotes the living wage and highlights the importance of } \\
\text { reducing gender pay-gap and job flexibility. } \\
\text { - Highlights the gendered segregation in employment positions } \\
\text { referring to feminist concepts such as the «glass ceiling» and } \\
\text { «sticky floor» effects which prevent women from reaching } \\
\text { higher status and higher paid positions } \\
\text { - Gender pay gap } \\
\text { - The business pledge provides examples of how a business can } \\
\text { be socially, economically and environmentally sustainable. }\end{array}$ \\
\hline & $\begin{array}{l}\text { Silences: } \\
\text { - The underlying discrimination which allows for women to } \\
\text { work below their skillset. } \\
\text { - Organisations and institutions are structured in a way which } \\
\text { allows for inequalities to reproduce. } \\
\text { - Women are made to feel different as a minority in a } \\
\text { predominantly male environment. }\end{array}$ \\
\hline & $\begin{array}{l}\text { Disrupted/contested/contradictions/reconceptualization } \\
\text { - Many women today are working below their skillset as } \\
\text { business structures are free to discriminate. } \\
\text { - Women are portrayed as having untapped economic value } \\
\text { rather than human beings who have the right to work and } \\
\text { provide for their families. }\end{array}$ \\
\hline
\end{tabular}

Feminismo/s 35, junio 2020, pp. 95-125 


\section{REFERENCES}

Aavik, Kadri. «The animal advocacy movement in the Baltic states: Links to other social justice issues and possibilities for intersectional activism». Journal of Baltic Studies 49.4 (2018): 509-527.

Acker, Joan. «Hierarchies, jobs, bodies: A theory of gendered organizations». Gender E society 4 (1990): 139-158.

Acker, Joan. «From glass ceiling to inequality regimes.» Sociologie du travail 51 (2009): 199-217.

Allwood, Gill. «Gender mainstreaming and EU climate change policy». In The persistent invisibility of gender in EU policy. Elaine Weiner and Heather MacRae, eds. European Integration online Papers (EIoP), Special issue 1. 18 (2014): 1-26.

Attfield, Robin. Environmental ethics: An overview for the twenty-first century. New Jersey: John Wiley \& Sons, 2014.

Bacchi, Carol Lee. Women, policy and politics: The construction of policy problems. London: Sage, 1999.

Bacchi, Carol Lee. What's the Problem Represented to be: An introduction. Flinders University Adelaide. 10 February 2020. <https://scholar.googleusercontent.com/scholar?q=cache:VPCr4ijJw2MJ:scholar.google. $\mathrm{com} /+$ What $\% 27 \mathrm{~s}+$ the+Problem+represented+to+be\%3F+an+Introduction $+\&$ thl $=$ en\&as_sdt $=0,5>$.

Bacchi, Carol, and Joan Eveline. Mainstreaming politics: Gendering practices and feminist theory. Adelaide: University of Adelaide Press, 2010.

Bacchi, Carol, and Susan Goodwin. Poststructural policy analysis: A guide to practice. Basingstoke: Palgrave Macmillan, 2016.

Bagilhole, Barbara. Understanding equal opportunities and diversity: The social differentiations and intersections of inequality. Bristol: Policy Press, 2009.

Brohman, John. Popular development: Rethinking the theory and practice of development. Oxford: Wiley-Blackwell, 1996.

Cooper, Ann. A woman's place is in the kitchen»: The evolution of women chefs. International Thomson Publishing Services, 1998.

Cretney, Raven, and Sylvia Nissen. «Climate politics ten years from Copenhagen: Activism, emergencies, and possibilities.» Women Talking Politics (2019): 15.

Du Pont, Yann Robiou, M. Louise Jeffery, Johannes Gütschow, Joeri Rogelj, Peter Christoff, and Malte Meinshausen. «Equitable mitigation to achieve the Paris Agreement goals». Nature Climate Change 7. 1 (2017): 38-43. 
Food Tourism Scotland. Food Tourism Action Plan, 2019. 29 January 2020. <https://scottishtourismalliance.co.uk/wpcontent/uploads/2019/04/ FoodTourismStrategy.pdf>.

Gerson, Kathleen. «Moral dilemmas, moral strategies, and the transformation of gender: Lessons from Two Generations of Work and Family Change». Gender E Society 16. 1 (2002): 8-28.

Giddens, Anthony. «The politics of climate change.» Policy \& Politics 43.2 (2015): 155-162.

Harris, Deborah, and Patti Giuffre. ««The price you pay»: How female professional chefs negotiate work and family.» Gender Issues 27.1-2 (2010): 27-52.

Hulme, Mike. Why we disagree about climate change: Understanding controversy, inaction and opportunity. Cambridge: Cambridge University Press. UK, 2009.

Kendrigan, Mary Lou. Gender differences: Their impact on public policy. New York: Greenwood Publishing Group, 1991.

Kheel, Marti. Nature ethics: An ecofeminist perspective. Lanham, Maryland: Rowman \& Littlefield, 2007.

Koch, Shelley. Gender and Food: A Critical Look at the Food System. Lanham, Maryland: Rowman \& Littlefield, 2019.

Kronsell, Anna. «Gendered practices in institutions of hegemonic masculinity: Reflections from feminist standpoint theory». International Feminist Journal of Politics 7 (2005): 280-298.

Kronsell, Anna. «Methods for studying silences: gender analysis in institutions of hegemonic masculinity». In Feminist methodologies for international relations. New York: Cambridge University Press, 2006. 108-128.

Leach, Melissa. «Earth mother myths and other ecofeminist fables: How a strategic notion rose and fell». Development and change 38.1 (2007): 67-85.

Lenton, Timothy M., Johan Rockström, Owen Gaffney, Stefan Rahmstorf, Katherine Richardson, Will Steffen, and Hans Joachim Schellnhuber. «Climate tipping points-too risky to bet against.» Nature.Com (2019): 592-595. 10 February 2020. <https://www.oceanplan-project.com/ uploads/1/0/5/5/105562895/2019_lenton_et_al_-_cc_tiping_points.pdf>.

Levy, Barry S., and Jonathan A. Patz. "Climate change, human rights, and social justice.» Annals of global health 81. 3 (2015): 310-322.

McPhail, Beverly A. «A feminist policy analysis framework: Through a gendered lens.» The Social Policy Journal 2. 2-3 (2003): 39-61. 
Meinzen-Dick, Ruth, Chiara Kovarik, and Agnes R. Quisumbing. «Gender and sustainability.» Annual Review of Environment and Resources 39 (2014): 29-55.

Merchant, Carolyn. «The Death of Nature: Women, Ecology, and the Scientific Revolution». San Francisco: Harper \& Row (1980): 348.

Moore, Jason. «The Rise of Cheap Nature». Sociology Faculty Scholarship. Binghamton University, 2016. 10 February 2020. <https://orb.binghamton. edu/cgi/viewcontent.cgi? article=1001\&context=sociology_fac $>$

Morrison, Ann M., Randall P. White, and Ellen Van Velsor. Breaking the Glass Ceiling: Can Women Reach The Top Of America's Largest corporations? New Jersey: Pearson Education, 1987.

Moss, Kanter Rosabeth. «Men and Women of the Corporation, New Edition.» Cambridge (2008): 245-266.

Murray-Gibbons, Robert, and Chris Gibbons. «Occupational stress in the chef profession». International Journal of Contemporary Hospitality Management 19. 1. (2007): 32-42.

Nilsson, Gabriella. «Balls Enough: Manliness and Legitimated Violence in Hell's Kitchen». Gender, Work E Organization 20.6 (2013): 647-663.

Plumwood, Val. «Gender, eco-feminism and the environment.» In Controversies in environmental sociology. New York: Cambridge University Press, 2004. 43-60.

Ripple, William J., Christopher Wolf, Thomas M. Newsome, Phoebe Barnard, and William R. Moomaw. "World scientists' warning of a climate emergency.» BioScience, 2019. 10 February 2020.

Available from <https://academic.oup.com/bioscience/article/70/1/8/5610806>.

Rose, Jeff, and Adrienne Cachelin. «Critical sustainability: incorporating critical theories into contested sustainabilities». Journal of Environmental Studies and Sciences 8.4 (2018): 518-525.

Ruether, Rosemary Radford. New woman, new earth: Sexist ideologies and human liberation. New York: Seabury Press, 1975.

Scottish Business Pledge. The Scottish Government in partnership with businesses, 2019. Accessed on February 12 2020. Available from <https://scottishbusinesspledge.scot/>

Scottish Food Commission Recommendations from the Scottish Food Commission for the implementation of, and content for, the Scottish Good Food Nation Bill. Compiled on behalf of the Scottish Food Commission. Scotland, 2017. 10 February 2020. <https://www.gov.scot/binaries/content/documents/govscot/publications/corporate-report/2019/01/scottish-food-commission-final-report/

Feminismo/s 35, junio 2020, pp. 95-125 
documents/food-commission-final-report-december-2017/food-commission-final-report-december-2017/govscot\%3 Adocument/ Food\%2BCommission\%2Bfinal\%2Breport\%2B\%2BDecember\%2B2017.pdf> Scottish Government. Tackling Occupational Segregation in Scotland: a report of activities from the Scottish Government Cross-Directorate Occupational Segregation Working Group, 2008. 12 February 2020. <https://www2.gov. scot/resource/doc/236539/0064855.pdf>

Scottish Government. Climate Change (Scotland) Act, 2009. 2 February 2 2020. <http://www.scotland.gov.uk/Topics/Environment/climatechange/ scotlandsaction/climatechangeact>

Scottish Government. Recipe for Success -Scotland's National Food and Drink Policy. The Scottish Government, 2009. 10 February 2020. <https://www. gov.scot/publications/recipe-success-scotlands-national-food-drinkpolicy/>

Scottish Government. Recipe for Success: Scotland's National Food \& Drink Policy Becoming a Good Food Nation. Discussion Document, Edinburgh, 2014. 10 February 2020. <https://www.gov.scot/publications/ recipe-success-scotlands-national-food-drink-policy-becoming-good-food/>

Scottish Government. Fair Work Convention, 2016. 10 February 2020. <https:// www.fairworkconvention.scot/the-fair-work-framework/>

Scottish Government. Climate Change Plan. The Third Report on Proposals and Policies 2018-2032, 2018. 10 February 2020. <https://www.gov. scot/publications/scottish-governments-climate-change-plan-third report-proposals-policies-2018-9781788516488/>

Scottish Government. GoodFood Nation-Programme of Measures, 2018. 13 February 2020. <https://www.gov.scot/publications/good-food-nation-programmeof-measures/pages/4/>

Scottish Government. Good Food Nation proposals for legislation: analysis of consultation responses, 2018. 2 February 2020. <https://www.gov.scot/publications/ good-food-nation-proposals-legislation-consultation-analysis-report/>

Scottish Government. A fairer Scotland for women: gender pay gap action plan - gov.scot, 2019. 21 January 2020. <https://www.gov.scot/publications/ fairer-scotland-women-gender-pay-gap-action-plan/>

Scottish Government. Working on women and work. Close the Gap. 29 January 2020. <https://www.closethegap.org.uk/>. 
Scottish Tourism Alliance. Food Tourism Action Plan, 2019. 13 February 2020. <https://scottishtourismalliance.co.uk/wpcontent/uploads/2019/04/ FoodTourismStrategy.pdf>

SEPA. Waste (Scotland) Regulations 2012 - Guidance for Restaurants E Bars. 29 January 2020. <https://www.sepa.org.uk/media/40256/zerowaste_guidance_ restaurants-bars.pdf>

Steinberg, Ronnie J. «Gender on the agenda: male advantage in organizations». Contemporary Sociology. (1992): 576-581.

Thomson, Emily. «Do ends justify means? Feminist economics perspectives on the business case for gender equality in the UK labour market». e-cadernos ces 5 (2009). 29 January 2020. <https://journals.openedition.org/eces/298>

Thomson, Emily, and Naveed Hakeem. «Gender equality pays: the economic case for addressing women's labour market inequality». Glasgow Caledonian University Online, 2016. 21 January 2020. <https://researchonline.gcu.ac.uk/en/publications/gender-equality-pays-the-economic-casefor-addressing-womens-l>

UN General Assembly. United Nations Framework Convention on Climate Change, 1994. 5 February 2020. <https://legal.un.org/avl/ha/ccc/ccc.html>

Weaver, Miles, Steven Paxton, Hock Tan, and Kenny Crossan. «Cultivating responsible business in Scotland through the lens of the Scottish business pledge». Edinburgh Napier University, 2016. 5 February 2020. <https:// www.researchgate.net/profile/Miles_Weaver/publication/298354369_ Cultivating_Responsible_Business_in_Scotland_through_the_lens_of_the_ Scottish_Business_Pledge/links/56e8a4a508ae166360e526c8/CultivatingResponsible-Business-in-Scotland-through-the-lens-of-the-Scottish-BusinessPledge.pdf>.

Feminismo/s 35, junio 2020, pp. 95-125 